\title{
A Frente Única Antifascista (FUA) e o antifascismo no Brasil (1933-1934)*
}

\author{
Ricardo Figueiredo de Castro
}

\section{Introdução}

o dia 7 de outubro de 1934, na cidade de São Paulo, mais precisa-
mente na Praça da Sé, centro da metrópole paulista, houve um violento e sangrento confronto entre integralistas e antifascistas, a "Batalha da Praça da Sé", assim chamada por um dos seus memorialistas. ${ }^{1}$

Esse acontecimento concentrou um amplo leque de forças políticas e sociais e foi um importante momento da luta antifascista no Brasil, integrando uma série de eventos mundiais nos quais chocaram-se violentamente fascistas e antifascistas, como o que aconteceu em Paris em fevereiro daquele ano.

Nos anos 30 do século XX, a radicalização política fazia com que as disputas políticas e ideológicas extrapolassem os Estados nacionais e se tornassem questões internacionais, "transnacionais". ${ }^{2}$ A luta entre fascismo e antifascismo não fugiu a essa regra, pelo contrário, foi uma das mais internacionalizadas do período e uma das que mais entusiasmou a juventude e a intelectualidade ocidentais. Nos anos 30, a crise internacional do liberalismo foi aprofundada, em decorrência de eventos que abalaram ainda mais a sua já combalida hegemonia, entre os quais, o crack da Bolsa de Valores de Nova Iorque, o crescimento dos movimentos "fascistas" na Europa (França, Espanha etc.) e sua vitória na Alemanha e a vitória da Frente Popular na França e na Espanha. No início dos anos 30, portanto, o liberalismo passou a sofrer então significativa concorrência de outras propostas de or-

\footnotetext{
* Este artigo tem como base dois capítulos de minha tese de doutorado (Cf. Castro, Ricardo Figueiredo de Castro. Contra a guerra ou contra o fascismo? As esquerdas brasileiras e o antifascismo, 1933-1935. Niterói: 1999. Tese (Doutorado em História) — UFF.
}

Topoi, Rio de Janeiro, dezembro 2002, pp. 354-388. 
ganização econômica e política, tanto pela direita quanto pela esquerda, que acabaram marginalizando-o do debate político-ideológico internacional.

\section{As esquerdas e a crise do liberalismo}

Depois que ficou claro, no início dos anos 20, que a revolução havia desaparecido do horizonte do movimento comunista internacional, a Internacional Comunista (Comintern) ${ }^{3}$ passou a elaborar uma estratégia que levasse em conta o refluxo da onda revolucionária: a política de frente única, isto é, a união das várias forças da esquerda seria a forma encontrada para reagrupar as forças revolucionárias. A frente única foi uma questão teórico-política que, ao longo dos anos 20 e até 1934, recebeu várias interpretações.

Em 1929, o X Pleno do Comitê Executivo do Comintern formulou a teoria do "terceiro período" que considerava que o capitalismo estaria passando por uma crise estrutural que desencadearia uma iminente guerra imperialista. O movimento operário deveria, pois, lutar para que essa crise capitalista não se transformasse numa guerra imperialista contra a URSS, mas sim numa guerra civil revolucionária e, por último mas não menos importante, deveria evitar a ação maléfica da social-democracia. Esta se equipararia ao fascismo na capacidade de iludir os operários em prol da manutenção da dominação burguesa, o "social-fascismo". Em suma, além de acusar a social-democracia de aliada dos fascistas, o Comintern recusava-se a integrar qualquer frente única da qual participassem outras organizações de esquerda. Portanto, o Comintern aceitava apenas a frente única com os militantes de outros grupos políticos - a "frente única pela base". Ainda assim, essa união com os militantes social-democratas era concebida como uma maneira de mostra-lhes qual a verdadeira natureza "socialfascista” de seus partidos social-democratas. Essa concepção restrita da política de frente única do Comintern e de suas seções nacionais, os PCs, perdurou pelo menos até o final de 1934 quando ela passou a conceber a política de "frente popular". 4

A questão da frente única tornou-se então, na primeira metade dos anos 30, uma das principais questôes a dividir o movimento comunista 
internacional, entre stalinistas e Comintern, de um lado, e "trotskistas" $\mathrm{e}$ Oposição de Esquerda, de outro.

Os "trotskistas", articulados em torno da liderança política e teórica de Leon Trotsky, propunham a política de frente única de todas as organizações operárias como forma de fazer frente ao fascismo e lutar pelo estabelecimento das bases objetivas e subjetivas da revolução socialista. Colocavam-se, pois, terminantemente, contra o "o social-fascismo", apesar de considerar a social-democracia conservadora, não-revolucionária e "interessada principalmente em manter a estrutura democrático-parlamentar como a base estrutural para o seu socialismo". 'Ainda assim, para Trotsky, equipará-la ao fascismo seria um "absurdo teórico e conceitual e politicamente desastroso". P Portanto, entre 1930 e 1933, "Trotsky foi um dos mais ferozes oponentes do 'social-fascismo' e, por outro lado, um defensor da 'frente única"'8

O ano de 1933, especialmente o seu primeiro trimestre, foi desastroso para a democracia européia e para o movimento comunista internacional. Na Alemanha, onde a tradição operária e revolucionária havia viabilizado a existência de um partido social-democrata e de um partido comunista fortes, ${ }^{9}$ o vácuo político deixado pela crise de 1929 e pela política sectária do Partido Comunista Alemão contribuiu para facilitar a ascensão dos nazistas ao poder. ${ }^{10}$ As medidas tomadas por Hitler no ano deixaram a sensação de que a paz mundial estava ameaçada. Essa sensação de guerra mundial iminente era reforçada pela escalada do imperialismo japonês que, em 1932, iniciou a invasão e conquista do território chinês.

No mês seguinte, fevereiro, reuniu-se uma conferência plenária da Oposição de Esquerda internacional na qual foram definidas as 11 condiçôes de adesão a esta organização. A oitava condição previa o "reconhecimento da necessidade de uma vasta política de Frente Única”. ${ }^{11}$

\section{0 antifascismo no Brasil}

Os anos de funcionamento da Assembléia Nacional Constituinte (1933 e 1934) foram de grande agitação e turbulência na ainda precária e restrita sociedade civil brasileira. A crise de hegemonia no Estado brasileiro e as idas e vindas de Getúlio Vargas para resolver o problema da resis- 
tência da oligarquia paulista, entre outros fatores, propiciaram as condições para que a sociedade civil paulista criasse, nesse período, canais de intervenção política, como as várias organizações políticas que então surgiram e as manifestações privadas ou públicas que ocorriam periodicamente.

Assim, a crise ideológica e política do liberalismo transformou-se no Brasil numa questão política não apenas para as elites econômicas e políticas, que, ao longo dos anos 30, debateram uma alternativa viável para o liberalismo. Igualmente, permitiu que as classes médias, os trabalhadores manuais e os intelectuais, também participassem do debate, seja pela direita, com o fascismo, seja pela esquerda, com o socialismo e comunismo. O debate sobre as alternativas ao liberalismo na prática sofreu a concorrência do confronto entre o fascismo e o antifascismo. Este tornou-se divisor de águas político nos anos 30, em grande parte da Europa e, no caso que nos interessa aqui, no Brasil.

Fascismo e antifascismo confrontavam-se no Brasil desde os anos 20. Contudo, foi apenas a partir da fundação da Ação Integralista Brasileira (AIB), em outubro de 1932, que a disputa passou a integrar os temas políticos nacionais.

Os antifascistas italianos tiveram importante participação na luta antifascista no Brasil nos anos 20. Na década seguinte, sobretudo a partir de 1933, passaram a sofrer a concorrência dos antifascistas brasileiros, sobretudo dos "trotskistas" da LC e socialistas do PSB paulista, ${ }^{12}$ com os quais alguns deles se aliaram, liderados pelo socialista Francesco Frola. Este se tornou, assim, o elemento de ligação entre duas gerações (italianos e brasileiros) e duas correntes políticas de antifascistas (socialistas e comunistas). Certamente que essa aproximação de Frola e seu grupo da luta antifascista das esquerdas paulistas se deveu às suas concepções políticas e adesão ao Partido Socialista Brasileiro de São Paulo. ${ }^{13}$

Os anos 1933-1935 abarcam o período a partir do qual as esquerdas brasileiras passaram a se interessar politicamente pelo antifascismo e criaram organizaçóes que disputaram entre si a hegemonia política e organizacional na luta antifascista. Ademais, em 1934 o antifascismo socialista italiano, até então hegemônico em São Paulo, entrou em declínio, com o fechamento de seu mais importante jornal, La Difesa. ${ }^{14}$ 
O mês de janeiro de 1933 é o mês-chave para o início da ampliação da questão da frente única no Brasil e no mundo, quando, como vimos acima, os nazistas chegaram ao poder. Ainda nesse mês o dirigente “trotskista” Mário Pedrosa concedeu entrevista ao diário paulista A Platea no qual discorria sobre o Congresso Antiguerreiro realizado em Amsterdã, ${ }^{15}$ sob a iniciativa dos escritores Henry Barbusse e Romain Rolland e o papel da Oposição de Esquerda brasileira nesta questão. ${ }^{16}$

Nesse mês a Comissão Executiva ${ }^{17}$ da LC aprovou decisão de "se lutar pela formação de uma frente única antifascista em São Paulo”, segundo o depoimento de um dos seus integrantes. ${ }^{18}$ Ainda segundo esse relato, o Grupo $\mathrm{A}^{19}$ incumbiu-se de "levar a política de frente única aos debates do sindicato dos empregados do comércio".

Ainda em janeiro, no dia 20, o jornal A Platea (página 3) noticiou que a Comissão Executiva da União dos Trabalhadores Gráficos (UTG) de São Paulo, então dominada pelos "trotskistas", aprovou a decisão de se dirigir "a todas as organizações sindicais de São Paulo, propondo uma frente única".

A partir de fevereiro, o PCB e a LC, ou pelo menos seus militantes, participaram de reuniōes e conferências em São Paulo nas quais se discutiu a criação de uma organização inspirada no Congresso Antiguerreiro Internacional. No dia 7 desse mês, dia do gráfico, aconteceu uma reunião na sede da UTG de São Paulo que contou com a participação de representantes de várias "associaçôes de classe" ${ }^{20}$ Embora acreditemos que essa reunião tenha sido concebida e hegemonizada pela LC, que dominava então a UTG, certamente dela participaram militantes do PCB, senão como tais, pelo menos como representantes das "associações de classe". Tanto isso é verdade que se convocou então, para o dia 9 de fevereiro, a "reunião já marcada para o largo de S. José do Belém, 23, sob., sobre a 'Guerra', ${ }^{21}$ que efetivamente aconteceu no dia e local marcados e que originou o Comitê Antiguerreiro, do qual o PCB participaria e lideraria. Ainda que assim não tenha sido, os "trotskistas" consideravam-se então membros (ainda que expulsos) do PCB e, portanto, agiam para que o PCB criasse o Comitê segundo suas orientações particulares. Isso explica por que os "trotskistas" tiveram importante participação na sua fundação, bem como durante o ano de 1933. 


\section{PCB e o Comitê Antiguerreiro}

No dia 2 de março foi publicado em A Platea comunicado do Comitê Antiguerreiro paulista convocando para o dia seguinte reunião na sede da Lega Lombarda. Anuncia a recente fundação do "Comitê de Frente Única Antiguerreira de São Paulo", aderente do "Comitê de Frente Única Contra a Guerra Imperialista do Rio de Janeiro", e que o Comitê nacional seria filiado ao "Comitê Mundial de Luta Contra a Guerra". Se compararmos esse panfleto com a entrevista de Mário Pedrosa acima citada veremos que tanto o PCB quanto a LC disputavam a bandeira da luta contra a guerra e a filiação ao Comitê internacional contra a guerra. Mesmo após a fundação da FUA, os "trotskistas" atuaram no interior do Comitê Antiguerreiro, como vimos acima, ainda que com reservas e profundas críticas.

Cerca de um mês depois da primeira referência ao Comitê Antiguerreiro paulista temos as primeiras notícias do Comitê Antiguerreiro no Distrito Federal. Um panfleto do Comitê Antiguerreiro do Rio de Janeiro convocou para "a Grande Conferência da Frente Única Antiguerreira do Rio de Janeiro" que se realizaria na Escola Nacional de Belas Artes ${ }^{22}$ no dia 15 de março. ${ }^{23}$ É clara a autoria do PCB deste documento posto que ele se dirige aos militantes e não às organizações (a frente única pela base). ${ }^{24} \mathrm{Os}$ dois documentos do Comitê Antiguerreiro, as seçôes paulista e carioca, mostram a preocupação em citar os intelectuais e personalidades artísticas que apoiavam a luta antiguerreira. ${ }^{25}$

Em 23 de março os integralistas, tendo à frente Plínio Salgado, marcharam pela primeira vez na cidade de São Paulo. A ameaça fascista passava a ser encarada como algo cada vez mais palpável e perigoso, o que acelerou as ações das esquerdas paulistas para barrar-lhes o caminho.

Algumas semanas depois, no dia 11 de junho, durante cerimônia lembrando o assassinato do deputado socialista italiano Giacomo Matteotti, ${ }^{26}$ foi proposta pelo militante "trotskista" Aristides Lobo ${ }^{27}$ a formação de uma frente única antifascista. A escolha da data não foi gratuita. Certamente foi uma forma de homenagear os antifascistas italianos que, como vimos acima, travaram o primeiro combate contra o fascismo em terras brasileiras, e de conferir uma certa legitimidade histórica e política à nova orga- 
nização. Ademais, buscava-se chamar a atenção para o aspecto internacional do fascismo e a inspiração do integralismo no regime fascista italiano. Igualmente, um dos principais patrocinadores da idéia no interior da LC foi o "trotskista" italiano Goffredo Rosini. ${ }^{28}$ Finalmente, procurava-se dessa maneira conseguir o apoio de parcela da população paulista, a de origem italiana, que havia muito vinha sendo alvo da propaganda antifascista. Com isso, criaria-se uma base a partir da qual o movimento antifascista poderia ampliar-se para os outros grupos populacionais paulistas. Esse aspecto demonstra o importante papel da comunidade italiana na luta antifascista nos anos 20 e 30.

Enquanto isso, no dia 22 de junho, os anarquistas paulistas tentaram organizar um certo Comitê Antifascista. Mais uma vez, um agente policial secreto estava presente e registrou a reunião. ${ }^{29}$ Dois dias depois, em 25 de junho de 1933, domingo, foi fundada oficialmente a Frente Única Antifascista (FUA) no salão da Legião Cívica 5 de Julho. O intervalo entre as duas datas, três dias, mostra a intensa atuação de anarquistas e "trotskistas" na organização de instrumentos políticos para a luta antifascista.

\section{A Frente Única Antifascista}

Para dirigir a reunião em que seria fundada a FUA foi escolhido o dirigente do Partido Socialista Brasileiro de São Paulo (PSB paulista), o italiano Francesco Frola. ${ }^{30}$ A escolha desse nome não só homenageava mais uma vez o antifascismo italiano, como também firmava a aliança com os socialistas da seção paulista do PSB.

Participaram do evento fundador, além do PSB paulista, o Grêmio Universitário Socialista, a União dos Trabalhadores Gráficos (UTG), a Legião Cívica 5 de Julho, a Liga Comunista (LC), a seção paulista do Partido Socialista Italiano, a Bandeira dos Dezoito, o Grupo Socialista "Giacomo Matteotti", o Grupo "Italia Libera", a revista $O$ Socialismo e os jornais O Homem Livre e A Rua.

$\mathrm{O}$ rol de fundadores e dos aderentes da FUA demonstra o amplo leque de forças políticas que formava essa organização antifascista. O seu espectro político ia da esquerda tenentista, passando pelos socialistas brasileiros e italianos, pelos anarquistas, e chegando aos "trotskistas". A única 
força política importante de esquerda que não participou da fundação foi o PCB. Essa ausência justifica-se pela posição política da seção brasileira da IC que se recusava a participar de qualquer organização frentista e desprezava as outras correntes políticas da esquerda. Entretanto, em alguns momentos, sobretudo em fins de 1933, o comitê regional paulista do PCB participou da frente.

A FUA era formada por um núcleo central, cujo "núcleo duro" era composto pela Liga Comunista e o "núcleo mole" pelo Partido Socialista Brasileiro de São Paulo, do qual participava o grupo de Francesco Frola. Em torno desse núcleo gravitavam os anarquistas, antifascistas independentes e outros grupos de esquerda como a Frente Negra Socialista, além das participações esporádicas do PCB.

Os indivíduos que aderiram à FUA seriam basicamente aqueles que militavam nos partidos que a compunham e aqueles que trabalhavam junto ao $O$ Homem Livre. Coerente com sua proposta de frente única, e diferentemente do Comitê Antiguerreiro (ligado ao PC), a FUA não recebia a adesão de cidadãos isoladamente.

A "grande imprensa" não chegou a divulgar a FUA, embora mencionasse o aparecimento de $O$ Homem Livre, como foi o caso do jornal $O$ Estado de S. Paulo e do fascista Fanfulla. Quanto às publicações das esquerdas, a revista $O$ Socialismo chegou a publicar notícias sobre a fundação, os anarquistas publicaram folhetos apoiando a FUA e o PCB lançou, em algumas oportunidades, através principalmente do jornal $A$ Vanguarda Estudantil, campanha difamatória contra a frente. Portanto, a FUA teve em $O$ Homem Livre a definição de sua identidade política frente à sociedade civil paulista e, particularmente, em contraposição ao fascismo, representado pela AIB.

Ao que parece os anarquistas paulistas não conseguiram levar a frente o seu Comitê Antifascista e, seguindo seus princípios libertários, não aderiram à FUA. Dez dias depois à fundação da FUA, distribuíram o panfleto "Contra a horda fascista", ${ }^{11}$ por intermédio da Federação Operária de São Paulo, no qual explicam sua relação com a FUA e a luta antifascista: colocavam-se contra a frente única como tática de luta antifascista, mas permaneciam apoiando ações antifascistas e atuando em sua "vanguarda". A 
frente única antifascista era, pois, não apenas combatida pelo PCB mas também rejeitada pelos anarquistas paulistas.

Em 14 de julho ocorreu na sede da Lega Lombarda a primeira manifestação pública da FUA, presidida pelo "trotskista" Aristides Lobo e na qual foi lançado o "Manifesto da Frente Única Antifascista". ${ }^{32}$ É interessante a data escolhida para a primeira manifestação antifascista da FUA. A data comemorativa da Revolução Francesa mostrava a preocupação com a escolha de uma data simbólica para toda a esquerda que não podia ser apropriada por nenhuma das suas vertentes políticas, já que ela as precedia. Ela seria pois passível de a todos representar e não somente aos comunistas, "stalinistas" ou "trotskistas".

Após esse episódio, a FUA entrou em inatividade que perdurou até setembro quando $O$ Homem Livre conclamou as organizações que participaram da fundação a cumprir o seu papel. ${ }^{33}$ Essa inatividade teria sido causada pela crise pela "qual passava o PSB, em busca de uma identidade mais nítida que o diferenciasse da tendência de esquerda do outubrismo". ${ }^{34}$

Em setembro de 1933, o Comitê Regional (CR) paulista do PC, através de Hermínio Sacchetta, ${ }^{35}$ iniciou conversações com a FUA e, ainda que criticando os "trotskistas", concordou em assinar manifesto convocando os antifascistas a participar do comício de 14 de novembro de $1933 .{ }^{36}$ Entretanto, ainda que participando da FUA e, portanto, descumprindo a orientação política nacional do partido e do Comintern, o CR paulista tentava colocar-se como o orientador da frente, esvaziando assim o caráter frentista da FUA.

Assim, pela primeira vez, o PCB, o PSB e a LC conseguem participar simultaneamente de um evento público antifascista da FUA. Essa lua-demel do PCB com a FUA dura apenas três comícios: o de 14 de novembro, o 15 de dezembro e o 25 de janeiro de 1934 .

No mês de outubro de 1933 aconteceram dois eventos que mudaram a orientação política das esquerdas paulistas. No dia 1ํㅡㄹ aconteceu a II Conferência Nacional (Extraordinária) da LC na qual ela endossa a proposta de Trotsky e da Oposição de Esquerda de fundar a IV Internacional Comunista. ${ }^{37}$ A Oposição de Esquerda internacional deixa de considerar possível reformar o Comintern e suas seções nacionais, e assim conclama 
seus seguidores, os "oposicionistas de esquerda", a fundar uma nova organização comunista internacional. Na prática, a LC deixa de se considerar oposição de esquerda do PCB e passa, assim, a se ver como uma organização autônoma: a Liga Comunista Internacionalista (LCI). ${ }^{38}$ No dia 4, o PSB paulista elegeu um novo Diretório Central superando a fase de instabilidade orgânica e indefinição política. Além disso, a "nova direção declarou-se seguidora da 'doutrina de Marx' e decidida a inscrever-se na Internacional Operária Socialista (IOS)" ${ }^{39}$ Após ter resolvido sua crise interna, o PSB também participou da reunião convocatória do comício de 14 de novembro. ${ }^{40}$

O comício antiintegralista da FUA de 14 de novembro de 1933 realizou-se mais uma vez na sede da União das Classes Laboriosas com a presença de cerca de mil manifestantes. $\mathrm{O}$ evento sofreu uma tentativa de dispersão pelos integralistas, que logo recuaram. O episódio terminou com a prisão de alguns militantes antifascistas. ${ }^{41}$

Em 15 de dezembro aconteceu a mais importante reunião da FUA em 1933. Deu-se na Lega Lombarda contando com cerca de dois mil participantes e com a participação do PCB e do Comitê Antiguerreiro. Dentre as resoluções da FUA neste evento temos: a sua articulação com outras organizações antifascistas de outros estados para a formação de Frente Única Nacional e a convocação do proletariado paulista para a formação de uma frente sindical. ${ }^{42}$

Um indício da preocupação da FUA em receber a adesão do PC e a perspectiva deste de não aceitar os termos desta frente é o título do manifesto publicado pelo $O$ Homem Livre no dia 14 de dezembro: "Manifesto das Organizações Coligadas em Frente Única Antifascista”. Por que não apenas manifesto da Frente Única Antifascista? Dessa forma a adesão do PCB à FUA ficaria mais diluída!

Apesar do sucesso dos dois eventos, o Comitê Antiguerreiro e o PCB insistiam em se colocar como os seus únicos artífices. Neste ínterim, o Comitê Central do PCB, localizado no Rio de Janeiro, interveio no Comitê Regional paulista, "tentando fazer ver que a participação do PCB na FUA contrariava a linha política do partido, baseada na 'frente única pela base"”. 
O comício da FUA, comemorativo do aniversário de São Paulo, realizado em 25 de janeiro no largo da Concórdia, centro de São Paulo, foi impedido pela polícia e uma comissão do PSB foi à Região Militar tentar obter uma autorização de última hora. Antes do seu retorno, um militante do PCB tentou infrutiferamente abrir o comício. Ainda assim, alguns dirigentes fizeram curtos discursos interrompidos pela polícia montada.

Nessa ocasião, pressionado pelo Comitê Central, o Comitê Regional paulista do PC abandona a FUA e inicia uma violenta campanha contra ela e uma renhida disputa com a LC pelos dividendos políticos da luta antifascista. Assim é que o jornal paulista $A$ Vanguarda Estudantil, ligado ao $\mathrm{PCB}$, publica então duras críticas à FUA, chamando-a de "frente única de tapeação" que visava ofuscar a legítima frente única do Comitê Antiguerreiro, promovido pelo PCB desde o início de $1933 .{ }^{43}$

Em 24 de fevereiro de 1934 foi lançado o $22^{\circ}$ e último número de $O$ Homem Livre. O fechamento do jornal da FUA demostra as dificuldades políticas e financeiras pela qual ela passava. Os problemas pelos quais passava o PSB, a fragilidade orgânica da LC, a recusa a uma participação mais conseqüente por parte dos anarquistas e a decisão do PCB em deixar de colaborar certamente contribuíram para inviabilizar a continuação do jornal e dificultarão a continuação das atividades da FUA.

Podemos concluir que a FUA e o Comitê Antiguerreiro disputavam o mesmo espaço político e que este último fortaleceu-se, a partir do final de 1933, tirando espaço e força da FUA. Esta caracterizou-se basicamente como instrumento de propaganda contra o integralismo e organizadora de esporádicas manifestaçôes públicas contra a AIB.

Ao longo de 1934, à medida que perdeu seu principal órgão de propaganda e combate político, O Homem Livre e a FUA, os "trotskistas", passaram a se dedicar à construção da frente única sindical e eleitoral.

\section{A frente única sindical e eleitoral}

Em março de 1934 a LCI e a Coligação dos Sindicatos Proletários tentam obter autorização da polícia para realizarem, durante o $1^{\circ}$ de maio, ato de repúdio à política sindical varguista e às ameaças integralistas ao movimento operário. A autorização foi negada inúmeras vezes, mas final- 
mente liberada para recinto fechado. O comício de $1^{\circ}$ de maio foi realizado então no pátio do Palácio das Indústrias no Parque Dom Pedro II. Vários sindicatos estiveram representados, além da União dos Trabalhadores Gráficos, do PSB e da LCI.

Em suma, durante a maior parte de 1934 as organizações e militantes antifascistas que haviam aderido à FUA se dedicaram basicamente a organizar a frente única no campo sindical (Coligação dos Sindicatos Proletários) e no eleitoral (Coligação das Esquerdas).

Em meados de 1934 o PC realizou a sua I Conferência Nacional que fortaleceu o partido ao se escolher um novo Comitê Central que pôs fim à instabilidade organizacional que existia havia cerca de dois anos. Já em 23 de agosto de 1934, o PC organizou no Teatro João Caetano, no Rio de Janeiro, o I Congresso Nacional contra a Guerra Imperialista, a Reação e o Fascismo. ${ }^{44} \mathrm{O}$ antigo Comitê Antiguerreiro adquire força e visibilidade.

Enquanto isso, em São Paulo, o recém-fundado ${ }^{45}$ PSPB propõe uma frente eleitoral ao PCB, LC, PSB e Partido Trabalhista Brasileiro: a Frente Única Proletária. ${ }^{46}$ Em 28 de agosto $A$ Platea publicou o programa da Coligação das Esquerdas, integradas pela Coligação dos Sindicatos, LC e PSB e recusada pelo PCB. ${ }^{47}$

De agosto até final de novembro de 1934, foram realizadas várias tentativas de formação de uma frente única eleitoral e sindical, como a Coligação das Esquerdas, a Frente Única Proletária e a Frente Única Sindical.

\section{Fascismo e guerra: divergências teóricas}

Não havia consenso entre as esquerdas, sobretudo em suas principais forças, na abordagem da questão antifascista e na política a seguir. O PCB e a Liga Comunista tinham profundas divergências teóricas que podem se divididas em dois tipos.

Em primeiro lugar, quanto à natureza da ameaça fascista. Para o PC, o fascismo fazia parte da escalada das forças reacionárias e imperialista rumo a uma radicalização internacional dos fatores que haviam configurado a crise econômica capitalista e que acirravam as condiçôes cada vez mais presentes para a eclosão de uma nova guerra mundial. O PC não considerava a especificidade histórica do fenômeno fascista, ou seja, este se equiparava 
às outras formas de fenômenos autoritários e não merecia, portanto, uma política específica. Antes de lutar contra o fascismo, o PC propunha a luta "contra a guerra". A luta contra a guerra não significava uma política defensiva, pelo contrário, considerava-a inexorável e uma antevéspera da revolução. Urgia, pois, esperar pela guerra e transformá-la em guerra civil, que poderia criar as condições para o estabelecimento de um governo revolucionário.

Por outro lado, a Oposição de Esquerda internacional — baseada nos escritos de Trotsky sobre a ascensão do nazismo na Alemanha - propunha que o estabelecimento do fascismo não seria um caminho para acirrar a luta de classes e, assim, abrir caminho para a guerra civil, mas sim uma inviabilização do movimento operário e da existência das esquerdas. Assim, para os "trotskistas" da LC o principal inimigo a combater era o fascismo, e para tanto seria necessária a política de "frente única". Os "trotskistas" não tinham nenhuma confiança nos social-democratas, mas consideravamnos aliados contra uma ameaça muito maior ao movimento operário independente - o fascismo.

$\mathrm{Na}$ verdade, essa questão da importância política do fenômeno do fascismo está relacionada a diferentes visões quanto às condições objetivas de deflagração de um processo revolucionário. Os "stalinistas" julgavam que estavam plenamente maduras as condições para a deflagração da guerra civil e do estabelecimento dos sovietes. Durante greve da Cantareira, ${ }^{48}$ ocorrida em meados de 1934, por exemplo, o Birô Político do PC propôs aos militantes que trabalhavam na organização do movimento a criação de sovietes na cidade de Niterói, idéia prontamente rechaçada pelo dirigente sindical pecebista Grazzini. ${ }^{49}$ Ainda em outubro, o Jornal do Povo publica charge intitulada, "o fuzil na mão do trabalhador". No dia 9 deste mês, Honório de Freitas Guimarães (Martins), respondendo à carta de Plínio Mello no qual este acusa o PCB por não ter aceito a frente única para concorrer às eleições (Frente Única Proletária), critica a participação das esquerdas nas eleições e a necessidade de ampliar as greves e lutar pela "Revolução Operária e Camponesa, aos Conselhos (Soviets) de Operários, Camponeses, Soldados e Marinheiros." ${ }^{50}$

Os "trotskistas", por outro lado, julgavam que não havia condições objetivas e subjetivas para a deflagração da revolução. Era, pois, necessário 
lutar pela reconstitucionalização do país, que propuseram ainda em 1931, e pelo fortalecimento das esquerdas na vida política nacional como forma de preparar as "condições subjetivas" e estar preparado, assim, quando as "condições objetivas" aparecessem. O fascismo era um empecilho para que isso acontecesse, e o fortalecimento de uma organização declaradamente fascista tornava a ameaça mais presente.

Para o PCB o fascismo era, teoricamente, uma questão menor, talvez até contribuísse para acirrar a luta de classes e, assim, abrir caminho para a guerra civil: o "quanto pior melhor". Para a LC, lutar contra o fascismo era a única saída para a existência das esquerdas e do futuro do socialismo. Isso não significa que o PCB tenha se furtado de lutar contra os integralistas, pelo contrário. $\mathrm{O}$ que acontecia é que esse era visto como momento da luta mais geral contra a "reação".

O segundo ponto de divergência entre os pecebistas e os "trotskistas" era a questão da frente única, já analisada acima. Lembramos apenas que a "frente única pela base" do PCB não admitia nenhuma forma de união de cúpula com os outros partidos de esquerda, apenas com os seus militantes. Desse modo, durante os anos de 1933 e 1934, o PC lutou contra todas as tentativas das outras esquerdas, LC, PSB paulista, PSPB e PTB, de formar frente únicas para luta contra o fascismo, concorrer às eleições e organizar uma frente sindical contra a política varguista.

$\mathrm{O}$ antifascismo das esquerdas brasileiras teve, assim, que se articular com duas ordens de problemas: a definição da importância da ameaça fascista ("contra a guerra" ou "contra o fascismo") e a tática política a seguir para lhe fazer frente ("frente única pela base" ou "frente única").

\section{Jornal 0 Homem Livre}

Cerca de um mês antes da fundação da FUA um grupo de jornalistas do jornal vespertino paulista Diário da Noite $e^{51}$ lançou um jornal antifascista, $O$ Homem Livre, ${ }^{52}$ que se tornaria o principal instrumento de propaganda antifascista da FUA. Escolheram o secretário de redação do Correio da Tarde, Geraldo Ferraz, como seu redator-chefe, pelo fato de não ser ligado a nenhuma organização política; o advogado José Pérez ${ }^{53}$ como diretor-gerente e Mário Pedrosa como seu secretário. ${ }^{54}$ A sua primeira edição 
é datada de 27 de maio de 1933 e contou com artigos assinados incusive sob pseudônimos de José Pérez, Mário Pedrosa, Lívio Xavier, Aristides Lobo, Goffredo Rosini, Geraldo Ferraz e Miguel Macedo, tendo sido ilustrada pelo gravador Lívio Abramo.

Mesmo com todos os problemas financeiros, O Homem Livre tinha qualidades técnicas e editoriais. Sua diagramação era profissional, publicava charges oriundas de jornais estrangeiros, era ilustrado com gravuras do artista plástico Lívio Abramo, utilizava-se dos serviços de agências de notícias internacionais, tinha seçôes fixas sobre artes plásticas, cinema, economia, cultura, ciências etc. Essa qualidade do jornal deve-se ao fato dele ser produzido por jornalistas e gráficos profissionais, muitos dos quais ligados ao jornal Diário da Noite.

A primeira edição de $O$ Homem Livre é datada do dia 27 de maio de 1933. Nessa edição o editorial "Contra o fascismo" já anuncia claramente quais eram os objetivos do jornal. É sintomático que já no primeiro número o jornal se preocupe em defender a idéia de que o principal inimigo a ser combatido naquele momento era o fascismo. Isso demonstra que não havia consenso entre as esquerdas. Não devemos nos esquecer de que o PCB considerava que fascismo era um sintoma da gravidade da crise capitalista mundial e que esta estaria gestando uma guerra imperialista contra a União Soviética. Mais do que lutar contra o fascismo e contra a guerra, os comunistas ligados ao Comintern deveriam se esforçar para que essa guerra imperialista se transformasse numa guerra civil revolucionária. Portanto, o jornal O Homem Livre — sob hegemonia dos "trotskistas" da LC que conheciam muito bem o PC e sua importância para a luta antifascista —, se preocupou, desde o início, em travar um combate propagandístico contra o fascismo em geral e os integralistas em particular, mas, também, e não menos importante, em combater a posição da Internacional Comunista e do PC de não se preocupar em lutar diretamente contra os fascistas.

A verdadeira campanha de desmistificação das virtudes do fascismo em todas as suas formas, feita nas páginas de $O$ Homem, tinha no humor uma de suas principais armas de contrapropaganda. Foram publicadas várias charges originalmente editadas em jornais estrangeiros, como o Daily Express e The Nation, e editados ainda vários artigos que procuravam analisar o lado satírico, quando não tragicômico, do fascismo e do integralismo. 
É interessante notar que, apesar da preocupação dos redatores e editores de $O$ Homem Livre em desqualificar o fascismo e o "arremedo de fascismo no Brasil" — o Integralismo-, sempre procuraram fazê-lo recorrendo a argumentos "racionais" e político-ideológicos.

Poderíamos dizer que $O$ Homem Livre ${ }^{55}$ foi o principal instrumento de ação política da FUA, pois ele se constituiu no seu principal veículo de divulgação, bem como no seu mais importante veiculador de propaganda antifascista. Além disso, O Homem Livre se constituiu num importante espaço de sociabilidade da intelectualidade antifascista paulista no qual interagiram intelectuais antifascistas e progressistas (advogados, jornalistas, professores universitários etc.) de várias tendências políticas (pecebistas, socialistas, "trotskistas", anarquistas). ${ }^{56}$

Durante toda a existência da FUA houve uma tensão permanente em relação à participação do PCB: buscava-se o seu apoio mas criticava-se sua política em relação ao fascismo. A LC compreendia a importância do apoio do PCB e, por isso, sempre o procurou para que tomasse parte da FUA. $\mathrm{Na}$ verdade, conforme já analisamos em outra parte deste trabalho, os "trotskistas" da LC se consideravam militantes comunistas que lutavam para levar a IC e suas seções nacionais ao verdadeiro caminho revolucionário - aquele baseado nos ideais de Lenin dos quatro primeiros congressos da IC. ${ }^{57}$ Desse modo, ao proporem a formação de uma frente única antifascista, eles queriam que esta se tornasse a política do PCB, e não que este partido ficasse isolado desse processo.

Podemos notar que à medida que avança o segundo semestre de 1933 , nas páginas de $O$ Homem Livre, o fascismo torna-se um perigo iminente cada vez mais presente, graças ao crescimento visível da Ação Integralista Brasileira. A partir de outubro, a AIB torna-se um tema recorrente do jornal. Na edição de 21 de outubro de 1933 (a 17ª) o editorial demonstra preocupação com a AIB: "A corja integralista ameaça! Antifascistas de pé! Pela organização imediata dos grupos de defesa" (1 página). Na mesma página noticia-se que o número 3 do órgão da AIB paulista, O Integralista, publicara lista dos seus inimigos, entre os quais a FUA. Conclama-se então que a FUA se reúna para tomar medidas práticas. Apesar dessa constatação e da necessidade de aumentar os esforços de publicação para fazer 
frente ao crescimento integralista em São Paulo, o Homem Livre, a partir dessa edição, passará a ser publicado quinzenalmente. Até a sua última edição, em fevereiro do ano seguinte, serão publicados apenas mais 5 ediçôes.

Nas últimas edições deste ano os integralistas são duramente atacados e seu aspecto caricatural e demagógico realçado. Entendem o recado e a importância de calar a FUA tanto que participam de todas as manifestações públicas (em espaço aberto ou fechado) que a FUA patrocina, procurando intimidar os seus integrantes. A FUA realiza o mesmo expediente. Em novembro e dezembro acontecem os maiores enfrentamentos, em 1933, entre a FUA e a AIB.

Em 14 de novembro realizou-se um comício da FUA no Salão Celso Garcia, sede da Associação das Classes Laboriosas, que contou com cerca de mil participantes e sofreu a agressão de integralistas que tentaram acabar com o evento, sem sucesso. ${ }^{58}$ Após a saída a polícia perseguiu e prendeu vários dos participantes. ${ }^{59}$

Conhecedores da importância tática que a AIB conferia ao controle simbólico do espaço público, os antifascistas também compareciam a todos os eventos promovidos pelos integralistas. A tática antifascista empregada pela FUA tinha dois pólos: a propaganda, ou melhor, contrapropaganda veiculada nas páginas do seu principal veículo de divulgação, $O$ Homem Livre, e a agitação política caracterizada nos comícios e, sobretudo, contracomícios.

Desse modo, o antifascismo da FUA era essencialmente defensivo. E não poderia ser de outro modo, devido às condições políticas e históricas do momento.

A pequena força numérica e política das organizações que a compunham; a simpatia e até adesão que alguns setores da sociedade paulista tinham pela AIB; a penetração que o fascismo tinha conseguido junto à comunidade italiana paulista, entre outros motivos, limitavam o poder ofensivo do antifascismo nessa conjuntura, ainda mais quando patrocinado pelas esquerdas. Estas não tinham de disputar espaço político apenas com a direita integralista: também precisavam preservar sua existência das constantes ondas de repressão política oriundas das polícias políticas. 


\section{A nova Constituição acirra a luta política}

A promulgação da Constituição federal em 16 de julho de 1934 iniciou uma nova fase da vida política brasileira. $\mathrm{O}$ mês de julho trouxe ainda outras novidades com importantes repercussōes no sindicalismo e nas esquerdas: uma nova lei de sindicalizacão e um novo ministro do Trabalho. ${ }^{60}$ O novo ministro, Agamenon Magalhães, aumentou a repressão sobre o movimento sindical independente, o que levava à prisão de suas principais lideranças. As esquerdas, LCI e PC, sobretudo, lutavam para barrar a implantação da lei de sindicalização, seja criando as "oposiçōes" sindicais dentro dos sindicatos oficiais, seja resistindo com a estrutura sindical vigente.

A partir de julho os acontecimentos políticos se precipitam. O segundo semestre de 1934 caracterizou-se politicamente, de um lado, pelo confronto direto entre a AIB e as esquerdas e, de outro, pela busca da articulação política da unidade das forças de esquerda, no campo sindical, eleitoral e antifascista.

Todos conspiravam, seja durante os trabalhos iniciais da Constituinte, seja já durante o ano de 1934. Parte das forças de direita, articuladas em torno do presidente Getúlio Vargas, considerava que essa era uma Carta Magna sem condiçôes de ser cumprida, pois situaria importantes empecilhos à ação soberana do Estado, visto por esse grupo como o instrumento da modernização nacional. ${ }^{61}$

Outra, mais radical, composta pelos integralistas, preparava-se para substituí-la pelo Estado Integral. Os liberais não se identificavam com ela pois consideravam que os ideais liberais não estavam suficientemente contemplados. Quanto às esquerdas, o PC, por exemplo, sustentava que já se vivia uma crise revolucionária durante a qual deveriam ser criados sovietes para preparar a insurreição. Quanto aos "trotskistas" da LCI e os socialistas do PSB, lutavam para ampliar os espaços políticos nos parlamentos estaduais e federal. Setores das esquerdas e das direitas esperavam a primeira oportunidade para descartar a Constituição ou, pelo menos, reformá-la. ${ }^{62}$

A radicalização política pode já ser percebida desde pelo menos abril de 1934. No dia 20, treze dias ${ }^{63}$ após o início da votação da Constituição, aconteceu o primeiro de uma série de desfiles integralistas em importantes 
cidades brasileiras. Neste dia desfilaram cerca de 4.000 pessoas pelas ruas do Rio de Janeiro. ${ }^{64}$ Esse fato demonstra um claro fortalecimento organizacional e político da AIB. ${ }^{65}$

Cerca de um mês depois, no dia 24 de junho, ocorreu um desfile integralista na capital paulista, contando com cerca de 3.000 pessoas. ${ }^{66} \mathrm{Uma}$ semana depois, no dia 2 de julho, feriado na Bahia, ${ }^{67}$ cerca de 400 integralistas fizeram um desfile pelas ruas de Salvador. ${ }^{68} \mathrm{Na}$ semana seguinte, dia 9, foi aprovado o texto final e, dia 16, foi finalmente promulgada a Constituição na capital federal. Nesse mesmo dia, do outro lado da Baía de Guanabara, em Niterói, encerrou-se a I Conferência Nacional do PCB que, entre outras coisas, institucionaliza um novo grupo dirigente. $\mathrm{O}$ partido preparava-se para a insurreição.

Entrementes, as esquerdas efetivam os primeiros contatos para a criação de coligações eleitorais visando às eleições parlamentares de outubro. Assim, no dia 6 de agosto, A Platea publicou a proposta do recém-criado Partido Socialista Proletário do Brasil (PSPB), ${ }^{69}$ feita à LCI, ao PSB, ao Partido Trabalhista do Brasil (PTB) ${ }^{70}$ e ao PCB, de formação de uma "frente única proletária" no Distrito Federal e no Estado do Rio de Janeiro. ${ }^{71}$ Antes que o mês acabasse, $A$ Platea publicou, no dia 28, programa da Coligação das Esquerdas formada pela Coligação dos Sindicatos Proletários, a LCI e o Partido Socialista para concorrer às eleições em São Paulo. ${ }^{72}$

Coerente com sua política de frente única apenas pela base, conforme orientação do Comintern referendada na I Conferência Nacional de julho de 1934, o PCB recusou-se a participar de qualquer coligação eleitoral. A Classe Operária, do dia 12 de setembro (número 169), responde negativamente à essas propostas através do documento "Manifesto do PCB dirigido aos trabalhadores do PSPB". ${ }^{73}$ O próprio título do texto demonstra que o PCB não aceitava fazer uma frente única com as outras organizações de esquerda, mas apenas com os trabalhadores a elas ligados, isto é, frente única "só pela base".

O PCB organizou ainda, no dia 23 de agosto, o primeiro evento político de grandes proporções patrocinado pelo Comitê Antiguerreiro, o I Congresso Nacional Contra a Guerra Imperialista, a Reação e o Fascismo. O evento transcorreu no Teatro João Caetano, ${ }^{74}$ após concentração e co- 
mício na Praça Cristiano Ottoni e passeata de cerca de 3.000 pessoas pela rua Marechal Floriano Peixoto e avenida Passos. O evento terminou em conflito com as forças policiais, o que deixou algumas vítimas fatais. Esse entrevero tornou-se, até o assassinato do jovem Tobias, ${ }^{75}$ a principal peça de propaganda política do PCB contra a política reacionária ("a reação") da nova fase do governo Vargas.

Desse modo, a AIB e as esquerdas disputavam a atenção das massas urbanas e organizavam eventos que procuravam superar em magnitude os do concorrente. $\mathrm{O}$ confronto direto era iminente...

As greves se sucediam e radicalizavam ainda mais a situação política nacional, o que preocupava Vargas, levando a anotar em seu diário no dia 27 de agosto de 1934:

A greve da Cantareira ameaça estender-se a outras empresas de transportes. Há intenso trabalho dos comunistas na Central, no ônibus, entre os chauffeurs, padeiros, marceneiros etc. O general Góis preocupa-se muito impressionado com o trabalho dos comunistas e sua ação no Exército, principalmente entre os sargentos. ${ }^{76}$

Em setembro as esquerdas conseguem realizar mais dois grandes eventos no Distrito Federal e em Niterói. No dia 15, um sábado, realizou-se em Niterói, na sede da Federação Proletária do Estado do Rio, ${ }^{77}$ o I Congresso Estudantil contra a Guerra Imperialista, a Reação e o Fascismo. A concentração para o evento aconteceu defronte à estação das barcas (Cantareira) na praça mais importante da cidade, a Praça Martim Afonso. Mais uma vez, agentes da polícia política estavam presentes e redigiram um relato "jornalístico" do evento.

No sábado seguinte, dia 22 de setembro, agora na capital da República, o Comitê Estudantil de Luta Contra a Guerra e o Fascismo promoveu um comício na Praça da Harmonia. O agente policial presente redigiu relatório no qual afirmava que haviam tomado parte "um grande número de conhecidos comunistas, tendo um dos oradores incitado a massa a cerrar fileiras em torno do Comitê e enfrentar as iras da burguesia". ${ }^{78}$

Outubro estava prestes a começar e com ele uma nova fase da luta antifascista. Embora a FUA não tenha conseguido se transformar num amplo movimento de massas, nem mesmo na cidade de São Paulo, a sua 
tática dos "contracomícios", o último (e decisivo) dos quais aconteceria neste outubro, evitou momentaneamente, pelo menos até meados de 1935, que a AIB transformasse o seu crescimento numérico em conquista do espaço público. Assim, as esquerdas paulistas organizadas na FUA (ou a sua margem) evitaram, em 1933 e 1934, que os integralista realizassem a sua "Marcha sobre São Paulo”. Quando a AIB se recupera em 1935, ele terá pela frente um adversário em pé de igualdade, a ANL.

\section{"A batalha da Praça da Sé" e os seus desdobramentos políticos}

Entre outubro e dezembro de 1934 a situação política se precipitou. O país estava prestes a pôr à prova a recém-promulgada constituição federal com as eleições parlamentares federais e constituintes estaduais e para o Congresso Nacional, previstas para 14 de outubro. ${ }^{79}$

Outubro é o ponto de inflexão do antifascismo brasileiro neste artigo. Essa conjuntura também é muito importante para o antifascismo. Neste mês a contenda entre as duas principais propostas de luta antifascista Comitê Antiguerreiro e FUA — chegou então a derradeira definição. Por outro lado, a renhida disputa pelo espaço público que esquerdas antifascistas travavam desde o ano anterior com a Ação Integralista Brasileira (AIB) teve então um desenlace sangrento. As disputas entre a AIB e as esquerdas antifascistas pelo espaço público chegam, finalmente, ao confronto direto em espaço público aberto.

No dia 3 de outubro, na cidade de Bauru, interior de São Paulo, ocorreu um violento conflito. Para esse dia, uma quarta-feira, feriado nacional em comemoração ao aniversário da Revolução de 30, havia sido agendada uma "palestra doutrinária" a ser ministrada pelo líder nacional da AIB, Plínio Salgado, cuja visita era prevista há meses pelos jornais locais. ${ }^{80}$

O Sindicato dos Empregados e Operários da Estrada de Ferro Noroeste do Brasil marcou uma "assembléia geral extraordinária” às 19h, ou seja, uma hora antes da palestra integralista. ${ }^{81}$ Nessa mesma hora iniciou-se um desfile integralista que, saindo da sede local da agremiação, acompanhada por tambores e taróis, buscou Plínio Salgado no hotel no qual estava instalado para levá-lo ao local da palestra — o que era uma praxe da AIB. 
Durante o trajeto o desfile passou a ser admoestado por populares que gritavam palavras de ordem antifascistas. Os ânimos foram se exaltando até que, numa determinada rua, estourou um violento tiroteio sem origem definida que resultou em um morto (Nicola Rosica) e quatro feridos, todos integralistas. Um dos principais acusados de ter participado da agressão aos integralistas era candidato a deputado estadual pela Coligação das Esquerdas. ${ }^{82}$ Esta coligação havia sido criada em São Paulo pela Coligação dos Sindicatos Proletários, Liga Comunista Internacionalista e o Partido Socialista no final de agosto. O PCB foi convidado mas recusou-se a participar.

Quatro dias depois, no domingo, o confronto atingiu uma dimensão maior, acontecendo no centro comercial e financeiro da capital paulista, segunda mais importante capital brasileira. Para esse dia, 7 de outubro, a AIB convocou os seus militantes para um evento político a ser realizado na Praça da Sé. O dia 7 de outubro era uma efeméride para os integralistas, uma de suas três principais celebrações. ${ }^{83}$ Nesse dia comemorava-se a proclamação do Manifesto Integralista ${ }^{84}$ numa cerimônia noturna que, segundo o cerimonial, deveria ser iniciada às 21 h e concluída à meia-noite: "a noite dos tambores silenciosos". ${ }^{85}$

É interessante notar que os únicos depoimentos nos quais se relacionam diretamente o contracomício antifascista com a FUA são de autoria de Fúlvio Abramo, ambos realizados em 1984: seu trabalho, publicado nos Cadernos Cemap, e a entrevista que concedeu à Folha de S. Paulo neste mesmo ano. Esses textos e o trabalho de Maffei, de $1984,{ }^{86}$ são os três únicos relatos minuciosos e contextualizados do episódio. Cada um deles defende a posição da organização ao qual pertenciam - LCI e PCB, respectivamente. ${ }^{87}$ Eles propóem teses excludentes quanto ao papel da FUA no evento e quanto à paternidade da convocação dos antifascistas. Cada um reproduz os argumentos que, à época, o PCB e a LCI faziam, ou seja, que a convocação teria sido feita pelo PCB ou pela FUA, respectivamente. É interessante que a memória desse evento tenha sido disputada desde então, com o PCB procurando diluir o papel da FUA e dos grupos de esquerda que a compunham, concomitantemente com a sobrevalorização do seu papel. Numa atitude conciliatória, Mário Pedrosa, em artigo editado 11 anos 
depois da "batalha", afirmou que: "nenhuma organização ou partido pode arrogar-se o mérito de ter conseguido sozinho aquele mobilização formidável de trabalhadores" ${ }^{88}$

Segundo Abramo, ${ }^{89}$ os "trotskistas", tão logo tomaram conhecimento da intenção da AIB de realizar a manifestação, decidiram impedi-la. Convocaram as organizações que haviam participado da FUA até o comício de 1 de maio para preparar um "contracomício". O seu secretariado, então recriado, formado por membros da LCI e do PSB, ${ }^{90}$ entrou em contato com o PC que, no entanto, recusou-se a aceitar uma direção central. ${ }^{91} \mathrm{~A}$ direção da FUA passou então a dividir tarefas e a definir a localização dos grupos antifascistas no interior da Praça da Sé.

Publicaram-se manifestos convocando-se militantes e simpatizantes a comparecer ao evento. O jornal carioca $A$ Pátria publicou, no dia 7, um desses manifestos, o da anarquista Federação Operária de São Paulo (FOSP):

És amigo da liberdade? - Queres que o Brasil marche para a paz e o progresso? - Repugna-te o crime e a bandalheira? - És amante da arte, da ciência e da filosofia? Pois então, guerra ao integralismo com todas as tuas energias. [...] Todos os homens de brio devem comparecer à praça da Sé, no dia 7 , às 15 horas, para impedir o desfile dos bárbaros integralistas. ${ }^{92} \mathrm{O} \mathrm{PC}$ publicou em A Platéa de 4 de outubro convocação a partidos (LCI, PSB, PTB) e sindicatos para "uma demonstração sob a bandeira da frente única, de combate ao fascismo, à guerra e à reação conservadora" e conclui que esta "seria o começo de uma frente única duradoura". ${ }^{93} \mathrm{O}$ ex-dirigente "trotskista" Abramo afirmou que o manifesto do PCB foi divulgado posteriormente àqueles "da LCI, da UTG e de outras entidades sindicais". ${ }^{94}$ É interessante notar que o PC se preocupava em colher frutos políticos do evento antifascista que se organizava, mesmo depois de ter combatido nos dois anos anteriores de todas as maneiras a frente única das organizações antifascistas.

Mais importante do que discutirmos que organização primeiro convocou a manifestação antifascista e qual a real extensão do papel da FUA neste processo é nos atermos a três questôes. Primeiro, pela primeira vez todas as forças antifascistas participaram em conjunto, ainda que sem direção totalmente centralizada, de uma manifestação pública de grandes proporções na segunda mais importante capital brasileira. E, em segundo lugar, esse evento tornou-se um símbolo da luta antifascista e da luta contra 
os aspectos reacionários da política nacional, o que o PCB chamava de "a reação".

É interessante lembrar que depoimentos sobre o confronto de Hermínio Sacchetta, Mário Pedrosa, Fúlvio Abramo, Miguel Reale, Lélia Abramo, Everardo Dias e Miguel Costa Filho não fazem menção explícita à FUA. ${ }^{95}$ Os que se referem à luta antifascista o fazem sem mencionarem a FUA. Francesco Frola publicou livro sobre o antifascismo no Brasil, no qual cita a FUA mas não faz nenhuma referência ao episódio da praça da Sé. ${ }^{96}$ O jornalista comunista Pedro Motta Lima publicou, em 1938, um livro sobre o nazismo no Brasil ${ }^{97}$ no qual menciona os confrontos em Bauru e na Praça da Sé, mas não fala da FUA, relacionando os acontecimentos ao processo que originou a ANL. ${ }^{98}$

No Rio de Janeiro, ainda no dia 7 de outubro, foi lançado o primeiro número do jornal O Homem do Povo, editado pelo jornalista Aparício Torelly e ligado ao PCB. ${ }^{99}$ Durante a semana seguinte o jornal dedicou várias reportagens ao episódio paulista, procurando descrever o acontecimento e fazer pilhéria da pretensa coragem dos integralistas. Uma das suas manchetes da semana seguinte ao evento foi: "Um integralista não corre, voa".

Outro jornal que também deu grande repercussão ao evento foi $A$ Pátria. Esse jornal terá uma importante atuação no movimento de oposição ao governo Vargas durante este último trimestre de 1934 até 1935, quando se tornou um dos principais jornais a apoiar a ANL.

O evento do 7 de outubro de 1934, a "Batalha da Praça da Sé”, tem uma grande repercussão positiva no Distrito Federal e, combinada com identificação do corpo do jovem militante Tobias Warshavsky, ${ }^{100}$ detona uma campanha política contra a política repressora do governo Vargas que se combina com o sentimento antifascista, ambos mesclados num sentimento contra a "reação".

No dia 9 de novembro foi publicado nas páginas de $A$ Pátria (páginas 1 e 3) abaixo-assinado de cidadãos cariocas e paulistas "pedindo a formação de uma comissão jurídica popular para o inquérito sobre a morte de Tobias Warshavsky”. Dois dias depois A Pátria (página 3) publica as bases da atuação da Comissão Jurídica e Popular de Inquérito (CJPI) criada para 
investigar as circunstâncias de sua morte. Este jornal tornou-se, assim, o grande patrocinador da Comissão.

Assim, o processo político do segundo semestre de 1934 é vital para compreender a questão do esvaziamento da proposta política da FUA e as circunstâncias do sucesso e das contradiçôes da ANL. A "Batalha da Praça da Sé" foi como que um breve renascimento para resolver uma contenda inadiável e realizar o confronto há muito previsto e esperado. Tão logo ele acabou a FUA perdeu a razão de ser.

A proposta de "frente única pela base" contra a guerra, a reação e, muito recente (e subsidiariamente), o fascismo, representada pelo Comitê Antiguerreiro do PCB, também se esgotara. Ao longo de 1934 o fascismo crescia na Europa e a Internacional Comunista, desde os meados do ano, já dava sinais de que a união com outras forças políticas seria possível. Nacionalmente, a nova ordem constitucional, a crescente repressão sindical e política, a radicalização política crescente e a ameaça mais presente da AIB formavam um novo quadro político.

Assim, o processo político que se acelerava nas últimas semanas de 1934 se encaminhava para a formação de uma frente muito mais ampla do que a FUA e o Comitê Antiguerreiro. Essa frente foi mais viável no Rio de Janeiro do que em São Paulo, entre outros motivos pela particularidade das suas esquerdas: a existência do PSPB e de uma seção da LCI, liderada por Hilcar Leite, mais pragmática do que a paulista.

No Rio de Janeiro, proposta encaminhada pelo PSPB de formação da Frente Única Proletária com o concurso da LCI, do PTB e do PCB finalmente chega a um encaminhamento positivo. É interessante notar que a Frente Única Proletária adota o novo nome Frente Única de Luta contra a Reação e o Fascismo e incorpora a legenda do PC, União Operária e Camponesa. ${ }^{101}$

A nova "frente única" não elegeu nenhum candidato. Mas isso não é o mais importante. $\mathrm{O}$ que deve ser destacado é que tanto a frente única antifascista da LCI quanto a "frente única pela base" contra a guerra e a reação (aí incluído o fascismo) foram superadas pela "Frente Única Contra a Reação e o Fascismo". Nome de conciliação, pois ele integra uma frente de organizações (e não de indivíduos), suprime a menção à "guerra" e coloca 
a questão fascista em pé de igualdade com a "reação". Ademais, essa nova frente única não era apenas eleitoral, pois previa a criação de uma brigada antifascista (ao gosto dos "trotskistas") e a "luta pela unidade e autonomia sindical”.

Assim, enquanto em São Paulo se preparava o confronto com os integralistas, no Rio de Janeiro se formava uma nova frente única na qual finalmente se incorporava o PCB. Esse partido conseguiu importantes concessões das outras entidades políticas, mas também recuou em suas posições sectárias, pois, pela primeira vez, aceitou unir-se formalmente a outras organizações políticas em uma frente única, cujo objetivo imediato era eleitoral.

Essa "frente única" foi logo superada pelos acontecimentos: fim do período eleitoral, impacto causado na classe média e entre os intelectuais pela "Batalha da Praça da Sé" e pela morte do jovem Tobias Warshavsky, crescente repressão policial etc.

A formação de uma ampla frente de setores progressistas (e não apenas a esquerda) a favor de amplas reformas na sociedade que caracteriza a "frente popular" diluiu a luta antifascista na luta mais ampla por reformas e contra as forças conservadores e reacionárias. A Comissão Jurídica e Popular de Inquérito, ainda no último bimestre de 1934, preparou o terreno para essa proposta ao rapidamente se viabilizar como uma entidade frentista e "apartidária" de luta contra o reacionarismo do governo Vargas.

As primeiras adesões a CJPI eram de indivíduos (militares, professores, advogados etc.), mas logo depois ela recebe a adesão de organizações (sindicatos, partidos etc.). A CJPI adensou-se politicamente entre novembro de 1934 e janeiro de 1935, ampliando paulatinamente sua atuação política. De uma simples comissão ${ }^{102}$ a CJPI lançou as bases para uma ampla aliança nacional libertadora, a ANL. ${ }^{103}$

O antifascismo da FUA foi derrotado politicamente pela ANL. Entretanto, colaborou para viabilizar as bases da união das esquerdas paulista e carioca ${ }^{104}$ e, não menos importante, mostrou aos integralistas que os antifascistas estavam alertas e que não seria fácil realizar uma "Marcha sobre São Paulo”. 


\section{Notas}

${ }^{1}$ Cf. Maffei, Eduardo. A Batalha da Praça da Sé. São Paulo: Brasiliense, 1984.

${ }^{2}$ Cf. Hobsbawm, Eric. A era dos extremos. São Paulo: Companhia das Letras: 1995. p. 157.

${ }^{3}$ A Internacional Comunista, ou Comintern (acrônimo de Kommunistische Internationale), foi criada em 1919 pelo Partido Bolchevique como o partido mundial da revolução, ou seja, os partidos comunistas eram considerados seções nacionais do Comintern.

${ }^{4} \mathrm{~A}$ frente popular concebia uma ampla aliança entre todas as forças políticas progressistas, diferentemente da frente única que se restringia à esquerda.

${ }^{5} \mathrm{Na}$ época o termo "trotskista" era a forma pejorativa dos militantes comunistas que apoiavam Stalin se referirem aos militantes comunistas que o criticavam, os autodenominados "bolcheviques-leninistas". Usamos o termo em parênteses para facilitar a narrativa.

${ }^{6}$ Knei-Paz, Baruch. The social and political thought of Leon Trotsky. Oxford: Clarendon Press: 1979, p. 351.

${ }^{7}$ Idem., p. 352.

${ }^{8}$ Idem, p. 353.

${ }^{9}$ O Partido Comunista da Alemanha (KPD) era o segundo maior partido de modelo bolchevique - o primeiro era o Partido Comunista da União Soviética - e o maior entre os que não estavam no poder.

${ }^{10}$ Em 30 de janeiro, Adolf Hitler foi convocado pelo presidente da República alemã, Hindenburgh, para chefiar um novo governo. Daí até 5 de março, quando realizaram-se eleiçōes parlamentares, nas quais o partido Nacional-Socialista conquistou maioria no Parlamento (Reichstag), Hitler ampliou e consolidou seu poder.

${ }^{11}$ Marie, Jean-Jacques. O trotskismo. São Paulo: Perspectiva, 1990, p. 57.

${ }^{12} \mathrm{O}$ Partido Socialista Brasileiro de São Paulo era a seção estadual mais forte do PSB fundado em 1933.

${ }^{13}$ Para maiores detalhes sobre as posições política de Frola ver nossa tese de doutorado (Castro. Ricardo Figueiredo de. Op. cit. p. 56 et passim).

${ }^{14}$ Para maiores detalhes Cf. Castro, Ricardo Figueiredo de. Op. cit, cap. 2.

${ }^{15} \mathrm{O}$ I Congresso Internacional de Amsterdam ("Contra a guerra e o fascismo") ocorrera entre 27 e 29 de agosto de 1932. Por intermédio de Willi Münzenberg, o Comintern desempenhou um papel central conseguindo atrair a intelectualidade européia, a francesa em particular, para a luta contra a guerra. (Cf. Furet, François. Le passé d' une illusion: essai sur l'idée communiste au Xxe siècle. Paris: Robert Laffont, 1995. p. 260.)

${ }^{16}$ Esta entrevista está transcrita em Carone, Edgard. A Segunda República (1930-1937). São Paulo: DIFEL, 1974. p. 392-394)

${ }^{17}$ Estavam presentes Mário Pedrosa, Lívio Xavier, Fúlvio Abramo, Manoel Medeiros e Anton Machek. (Cf. Abramo, Fúlvio. "7 de outubro de 1934 - 50 anos”. Cadernos Cemap, São Paulo: ano I, n. 1, p. 3-65, out. 1984. p. 68.) 
${ }^{18}$ Idem.p. 14.

${ }^{19} \mathrm{O}$ Grupo A era um agrupamento de jovens militantes paulistas que aderiu em bloco a LC, mantendo, contudo, sua identidade. Desse grupo faziam parte, além de Fúlvio Abramo, Lélia Abramo e Azis Simão, entre outros. (Idem, p. 17.)

${ }^{20}$ Confederação Geral do Trabalho, Federação Sindical Regional de São Paulo, União dos Empregados em Hotéis e Similares, União dos Empregados em Fábricas de Tecidos, União dos Trabalhadores da Light e União dos Profissionais do Volante. Estavam presentes também representantes da LC, como Aristides Lobo, Mário Pedrosa e João (da Costa) Pimenta que, ao se colocarem como membros da "oposição de esquerda" do PCB, foram identificados pelo agente policial como membros desse partido e não da LC. O agente os denomina "comunistas".

${ }^{21}$ É interessante notar como ao longo de 1933 a "frente única" vai se ampliando e se aproximando geograficamente do centro da cidade de São Paulo. As primeiras reuniōes organizadoras do Comitê Antiguerreiro aconteceram no largo de São José do Belém, no Belemzinho, a cerca de 4 quilômetros do centro da cidade. A fundação da FUA e os seus eventos posteriores e os do Comitê Antiguerreiro acontecem no coração da cidade, na Rua do Carmo e no Largo de São Paulo, respectivas sedes da Associação das Classes Laboriosas e da Lega Lombarda; além de espaços públicos abertos como o Parque Dom Pedro II e a Praça da Sé.

${ }^{22}$ Nessa ocasião a Escola funcionava nas dependências do Museu Nacional de Belas-Artes, no coração político e cultural da capital federal.

${ }^{23}$ Cf. Panfleto "Todos à grande conferência de FRENTE ÚNICA do Rio de Janeiro contra as guerras imperialistas" contido no dossiê do Comitê Antiguerreiro do Rio de Janeiro (no 8531), caixa 110 (Arquivo Público do Estado do Rio de Janeiro/Fundo DOPS).

24 “(...) Estudantes pobres e intelectuais, pequenos negociantes e todos os que estão sinceramente dispostos a lutar contra as Guerras de Rapina, numa verdadeira FRENTE ÚNICA, sem distinção de crenças políticas ou religiosas”, (Idem, Ibidem).

25 "Já hipotecaram solidariedade os seguintes intelectuais: professor Antonio Piccarolo, Alberto Seabra, Maria Lacerda de Moura, pintores Tarsila do Amaral e Paulo Rossi, dr. Osório César (do Hospital de Juquery), os jornalistas Nabor Cayres Brito, Affonso Schimdt, Antonio Figueiredo, Galeão Coutinho, Britto Broca, Agnello Rodrigues, Jayme Adour da Camara, Philemon Assumpção, Oswaldo Costa, etc. No Rio, aderiram a essa cruzada o dr. Roquette Pinto, diretor do Museu Nacional, professor Pinheiro Guimarães, da Faculdade de Medicina; dr. Maurício de Medeiros e muitos outros nomes notáveis nas ciências e nas letras". A Platea, 2 de março de 1933, p. 1.

${ }^{26}$ Matteotti tornou-se um símbolo da luta antifascista na Itália e internacionalmente depois de ter sido sequestrado e morto por um grupo armado semanas após pronunciar discurso no parlamento italiano contra fraudes eleitorais perpretadas pelo governo de Mussolini. (Cf. Palla, Marco. A Itália fascista. São Paulo: Ática, 1996, p. 38-39.

${ }^{27}$ Essa informação confere com as informações contidas em seu prontuário policial. Segundo este, "constitui ele, dos elementos intelectuais atualmente em S. Paulo, o que maior 
atividade está desenvolvendo. Bateu-se fortemente pela constituição de um organismo de união das esquerdas revolucionárias, que ainda não pode tornar-se realidade por causa das rivalidades existentes entre os diversos grupos extremistas." Documento n. 59 do Prontuário de Aristides Lobo [n. 37, vol. 1] do APESP/DOPS.

${ }^{28}$ Cf. Abramo. Op. cit., 1984, p. 15. Quando na direção do jornal La Difesa Francesco Frola convidou Rosini, em 1929, para participar do jornal, apesar deste não ter deixado artigos assinados. (Cf. Bertonha, João Fábio. O antifascismo socialista italiano em São Paulo nos anos 20 e 30. Campinas: 1993. Dissertação (Mestrado em História) — Unicamp, p. 109) Ainda segundo Bertonha ele era um dos poucos comunistas da colônia italiana paulista (Idem, ibidem)

${ }^{29}$ Arquivo Público do Estado de São Paulo, Fundo DOPS. Documento no 1 do Prontuário no 1581 ("Comitê Antifascista”).

${ }^{30}$ Francesco Frola conseguiu nesta época a cidadania brasileira, passando a assinar Francisco Frola. Para maiores detalhes da vida desse importante político de esquerda ver o ensaio biográfiico de Bertonha, João Fábio. Um antifascista controverso: Francesco Frola. Paper. 1997.

${ }^{31}$ Documento no 7 do prontuário no 1581 ("Comitê Antifascista") [Arquivo Público do Estado de São Paulo / Fundo DOPS. O documento está reproduzido em Castro, 1999. Op. cit., documento 1 do Anexo.

${ }^{32}$ Editado na edição de 17 de julho do $O$ Homem Livre e na edição de 16 de julho da revista do PSB paulista $O$ Socialista, p. 7.

${ }^{33}$ Cf. Abramo, 1984. Op. cit., p. 20-21.

${ }^{34}$ Del Roio, 1990. Op. cit., p. 239.

${ }^{35}$ Nascido em 1909, filiou-se ao PCB em 1932 e era, em 1934 com 25 anos, secretário de Agitação e Propaganda (Agit-Prop) do Comitê Regional paulista. (Del Roio, 1990, Op cit., p. 243). Faleceu em 1982. Seu acervo está depositado no Arquivo Edgard Leuenroth da Unicamp.

${ }^{36}$ Cf. Abramo, 1984. Op. cit. p. 22

${ }^{37}$ Cf. Karepovs, Dainis, Lowy, Michael, Marques Neto, José Castilho. Trotsky e o Brasil. In Morales, João Quartim de. História do marxismo no Brasil. vol. II: os influxos teóricos. Campinas: Ed. da Unicamp, 1995, p. 241.

${ }^{38} \mathrm{O}$ nome LCI é publicamente divulgado durante o comício de $1^{\circ}$ de maio de $1934 \mathrm{em}$ São Paulo. (Cf. Del Roio, 1990, Op. cit., p. 226.)

${ }^{39}$ Del Roio, 1990. Op. cit. p. 228.

${ }^{40}$ Cf. Idem, p. 239.

${ }^{41}$ Cf. Abramo, 1994. Op. cit. p. 22-23. Temos relatos desse evento e de seus desdobramentos tanto feitos pelo jornal oficial da FUA $O$ Homem Livre quanto por um agente policial. $42 \mathrm{O}$ interessante é que existem dois relatórios policiais em seqüência ( $\mathrm{n}^{\circ} 50$ e 51) que demonstram uma confusão dos seus redatores. O relatório no 50 descreve apenas o comício da FUA ocorrido no Salão da Associação das Classes Laboriosas (Rua do Carmo, 
25); já o de número 51 narra que o policial assistiu primeiro a um evento do Comitê Estudantil Antiguerreiro (CEAG) no mesmo endereço e logo depois saiu para prender manifestantes que saíam do evento da FUA na Lega Lombarda (sic). Como temos confirmação de que o evento da FUA aconteceu efetivamente na rua do Carmo, concluo que o primeiro relatório está correto e que o segundo confunde os endereços.

${ }^{42}$ Cf. Abramo, 1982. Op. cit. p.27.

${ }^{43}$ Cf. "Frente única de luta e frente única de tapeação" In Vanguarda Estudantil, janeiro de $1934, \mathrm{n}^{-} 2$, p. 2.

${ }^{44}$ Cf. Vianna, Marly de Almeida Gomes. Revolucionários de 35: sonho e realidade. São Paulo: Companhia das Letras, 1992, p. 242 e Canale, Dario. A Internacional Comunista e o Brasil: 1920-1935. In Tavares, José Nilo (Org.) Novembro de 1935: meio século depois. Petrópolis: Vozes, 1985, p. 121.

${ }^{45}$ O Partido Socialista Proletário do Brasil (PSPB) foi fundado em 1934 e teve importante participação nas ações políticas das esquerdas em direção à frente única sindical e eleitoral. ${ }^{46}$ Cf. Del Roio, 1990. Op. cit., p.246.

${ }^{47}$ Cf. Vianna, 1992. Op. cit., p. 243.

${ }^{48}$ Cantareira era o nome da empresa privada que administrava a ligação, por barcas, entre Rio e Niterói.

${ }^{49}$ Cf. Lima, Heitor Ferreira. Caminhos percorridos. São Paulo: Brasiliense, 1982, p. 178-179.

${ }^{50}$ Martins [Honório de Freitas Guimarães] O Partido Comunista do Brasil define a sua posição perante a Frente Única Proletária. Jornal do Povo, 9 de outubro de 1934, p. 2.

${ }^{51} \mathrm{O}$ jornal Diário da Noite pertencia a Assis Chateaubriand que criou em dezembro de 1930 o Diário da Tarde a ser publicado nas mesmas oficinas do primeiro. Portanto, eram jornais que não apenas pertenciam ao mesmo proprietário mas compartilhavam funcionários. O primeiro secretário de redação do Diário da Noite foi o jovem jornalista Geraldo Galvão Ferraz. (Ferraz, 1982, p. 93.) Este, por sua vez, era irmão da escritora e militante "trotskista” Patrícia Galvão, a Pagu.

${ }^{52}$ Cf. Abramo, 1984. Op. cit., p. 15.

${ }^{53}$ Cf. Ferraz, 1982, p. 105-106. José Pérez deixou suas funções no jornal a partir da $11^{\text {a }}$ edição (14 de agosto de 1933) e assinou pelo menos um artigo, "As explorações anti-semitas: sobre os protocolos dos Sábios de Sião". Pérez foi "esquecido" pela memorialística "trotskista" de Abramo. Isso não deve nos estranhar pois o trabalho de reconstrução da memória de uma época pressupõe também esquecimentos conscientes e/ou inconscientes.

${ }^{54}$ Em seu relato sobre a FUA Fúlvio Abramo não cita o nome de Pedrosa, mas afirma que era ele próprio que realizava as funções de secretário de $O$ Homem Livre, isto é, conseguir anunciantes, providenciar a produção do jornal, contatar pontos de venda etc. (cf. Abramo, 1984. Op. cit. p.16).

55 Foram editadas 22 edições, sendo a última a de 24 de fevereiro de 1934 . As edições tinham entre 4, 6 e 8 páginas dependendo das precárias condiçōes financeiras do jornal. 
Nessa mesma época existia um jornal homônimo no Distrito Federal, dirigido por Hamilton Barata e que foi editado até pelo menos 1935.

${ }^{56} \mathrm{O}$ outro instrumento de ação política da FUA foram as suas poucas, mas conturbadas e violentas, manifestações públicas, em espaços fechados ou abertos. Os antifascistas percebiam a importância da propaganda e da conquista do espaço público para a política fascista. Desse modo, procuraram sempre preparar uma manifestação para o mesmo local e hora daquelas previstas pelos integralistas. Estes faziam o mesmo. Os conflitos eram, pois, inevitáveis.

${ }^{57}$ Cf. Abramo, Fúlvio, Jarepovs, Dainis. (Org.) Na contracorrente da história: documentos da Liga Comunista Internacionalista (1930-1933). São Paulo: Brasiliense, 1987, p. 64, nota 25 .

${ }^{58}$ Cf. Del Roio. Op. cit., p. 240 e Abramo. Op. cit., p. 22-23.

${ }^{59}$ Relatório policial endereçado ao Delegado de Ordem Social (Ignacio da Costa Ferreira) e redigido por Joaquim A. Gentil, Documento nº 57 do prontuário de Aristides Lobo (no 37), 15 de novembro de 1933, p. 1.

${ }^{60}$ Cf. Gomes, Ângela de Castro. A invenção do trabalhismo. São Paulo; Rio de Janeiro, Vértice; IUPERJ, 1988, p. 189.

${ }^{61}$ Cf. seus Diários publicados em 1996: Em “14 a 16/06” escreveu: “Com a Constituição que está para ser votada, talvez seja preferível que outro governe. Não tenho dúvidas sobre as dificuldades que vou enfrentar, e talvez seja mesmo preferível que tome outro rumo, pois já começo a acreditar que, com tal instrumento de governo, será perdido o esforço. (p. 302); E, em "27 e 28/07" anotou: "É preciso uma diretriz segura e flexível para a monstruosa Constituição que devemos cumprir.” (p. 310) [grifos nossos]

${ }^{62}$ Os Diários de Getúlio nos permitem inferir que desde pelo menos julho de 1934 Vargas já demonstrava sua insatisfação com a Constituição recém-promulgada. $\mathrm{O}$ ataque contra ela não precisou esperar pelo Levante Comunista de novembro de 1935, e pelo golpe do Estado Novo, em novembro de 1937. Já em dezembro de 1934, com a interdição da Comissão Jurídica e Popular de Inquérito (A Pátria, 18 de dezembro de 1934, p. 1) e a instalação do Conselho Superior de Segurança Nacional na última semana do ano, funcionando às vistas de Getúlio, no Palácio do Catete (cf. Vargas. Op. cit. p. 347). Este Conselho iniciou os trabalhos para elaboração de projeto de lei "de defesa do Estado" que viria a se consubstanciar na Lei de Segurança Nacional, a "lei monstro", promulgada em 4 de abril de 1935.

${ }^{63} \mathrm{O}$ início das votações do texto final da Constituição aconteceu no dia 7 de abril de 1934 (Beloch, Israel, Abreu, Alzira Alves de (Coords.). Dicionário histórico-biográfico brasileiro, 1930-1983. Rio de Janeiro: Forense-Universitária; FGV/CPDOC/FINEP, 1984. 4 vol., p. 914.

${ }^{64}$ Cf. Trindade, Hélgio. O integralismo. Rio de Janeiro: DIFEL, 1974. p. 303.

${ }^{65}$ Durante o ano de 1933 ocorreu apenas um desfile e mesmo assim apenas quarenta pessoas participaram de um desfile ocorrido em 3 de abril de abril na cidade de São Paulo (Cf. Trindade. Op. cit. p. 302). No segundo semestre desse ano, a AIB patrocinou apenas eventos 
em ambientes fechados na capital paulista, e mesmo assim alguns não aconteceram por pressão da FUA.

${ }^{66}$ Cf. Trindade. Op. cit., p. 303.

${ }^{67}$ Nessa data comemora-se a expulsão das tropas portuguesas quando da proclamação da independência do Brasil.

${ }^{68}$ Cf. Trindade. Op. cit., p. 303.

${ }^{69} \mathrm{O}$ PSPB havia sido fundado dois dias antes e dele faziam parte, entre outros, Plínio Melo, militante carioca muito próximo dos "trotskistas". Esse partido terá um importante papel nas tentativas de formação de coligações eleitorais e sindicais neste segundo semestre de 1934.

${ }^{70} \mathrm{O} \mathrm{PTB}$, organização política do qual não obtivemos maiores informações, foi registrado em cartório no dia $1^{\circ}$ de abril de 1933 na capital federal e teve seus estatutos publicados no Diário Oficial da União de 31 de março de 1933 (Cartório do 3ํㅜ́́ㄷo de Títulos e Documentos, livro K-1, no 211, fl. 25, Arquivo Nacional).

${ }^{71}$ Cf. Del Roio. Op. cit., p. 246.

${ }^{72}$ Cf. Vianna. Op. cit., p. 243. O programa está transcrito em Carone. Op. cit., p. 408-412. ${ }^{73}$ Del Roio. Op. cit., 246.

${ }^{74}$ Segundo o relatório policial, "O Teatro João Caetano, apesar de vasto e comportar uma lotação superior a 2.000 pessoas, tornou-se pequeno para comportar a grande massa, que se estendeu pelas cadeiras, camarotes, balcões e galerias, ficando totalmente cheio com grande número de pé na platéia, corredores das frisas e camarotes, sendo que estes continham 10 a mais pessoas, em cada um."

${ }^{75}$ É interessante notar que Tobias Warshawsky foi um dos oradores no evento, falando em nome da Federação das Juventudes Comunistas (A Pátria, 15 de novembro de 1934).

${ }^{76}$ Vargas. Op. cit., p. 321.

${ }^{77}$ Localizava-se na Rua São Pedro, isto é, no centro comercial e político da cidade de Niterói; e perto da sede do poder legislativo do Estado do Rio de Janeiro.

${ }^{78}$ Relatório policial intitulado "Comitê de Luta Contra a Guerra Imperialista e o Fascismo", p. 16, folha 36, contido no dossiê "Relatório sobre atividades comunistas", no setor Comunismo, pasta 11 (DESPS/APERJ).

${ }^{79}$ Após a promulgação da Constituinte de 1934 em julho o Congresso constituinte foi transformado em ordinário e os mandatos dos deputados federais prorrogados até maio de 1935 . Os deputados eleitos em outubro de 1934 tomariam posse, portanto, em maio de 1935 .

${ }^{80}$ Possas, Lidia Maria Vianna. O trágico três de outubro: estudo histórico de um evento. Assis, 1992. Dissertação (Mestrado em História) — Unesp.

${ }^{81}$ Idem, p. 40.

${ }^{82}$ Idem, p. 68. 
${ }^{83}$ As outras duas principais cerimônias da AIB eram A vigília da nação e As matinas de abril. (Trindade. Op. cit. p. 202.)

${ }^{84}$ Este manifesto, criador da AIB, foi lançado em 7 de outubro de 1932.

${ }^{85}$ Cf. Trindade. Op. cit., p. 203.

${ }^{86}$ No depoimento que nos concedeu em 1996, Miguel Costa Filho afirmou que o relato de Maffei baseava-se em informações que ele próprio havia lhe concedido durante conversas informais sobre o evento e que, inclusive, Maffei nem estaria presente ao confronto.

${ }^{87} \mathrm{O}$ jovem Maffei não era filiado ao $\mathrm{PCB}$, mas provavelmente apenas militante da Juventude Comunista. Como se sabe a filiação aos quadros do PCB era um processo complexo e lento.

${ }^{88}$ Vanguarda Socialista, no 7, 12 de outubro de 1945. Apud Abramo. Op. cit.

${ }^{89}$ Cf. Motta. Op. cit., p. 42.

${ }^{90}$ Mário Pedrosa, Manoel Medeiros, J. Neves, Fúlvio Abramo e Antunes pela LCI e João Cabanas, Francisco Giraldes, Zoroastro Gouvêia e Waldemar Godói pelo PSB. (Cf. Abramo. Op. cit., p. 44.)

${ }^{91}$ Cf. Abramo. Op. cit., p. 44.

${ }^{92}$ Ver texto completo em Castro. Op. cit. documento 2 do Anexo. Os anarquistas, coerentes com sua doutrina, não participaram das deliberações da FUA mas não se furtaram a comparecer ao confronto.

${ }_{93}$ Publicado em Abramo. Op. cit., p. 82-83.

${ }^{94}$ Idem. p. 42.

${ }^{95}$ Cf. Abramo, Lélia. "A arte, a coragem, a beleza, a revolução" por Alípio Freire e Eugênio Bucci In Teoria e Debate, n. 5, jan./fev./mar. 1989, p. 12-21; Dias, Eduardo. Um imigrante e a revolução: memórias de um militante operário (1934-1951). São Paulo; Campinas: Brasiliense; Arquivo de História Social Edgard Leuenroth, 1983; Reale, Miguel. Memórias: destinos cruzados. São Paulo: Saraiva, 1986. vol. 1; Sacchetta, Hermínio, Pedrosa, Mário, Abramo, Fúlvio. "Um dia de luta e união”. Depoimentos a Paulo Sérgio Pinheiro. Revista Isto É. São Paulo, outubro de 1979; Entrevista concedida ao autor por Miguel Costa Filho em 27/01/96.

${ }^{96}$ Frola, Francisco. Recuerdos de un antifascista, 1925-1938. México: Editorial "Mexico Nuevo", 1939.

${ }^{97}$ Lima, Pedro Motta. El nazismo en el Brasil. Proceso del estado corporativo. Buenos Aires: Editorial Claridad, 1938. p. 48.

${ }^{98}$ A FUA foi uma organização de pouca visibilidade política, com a adesão precária dos grupos políticos que a compunham e que existiu basicamente em função do trabalho de agitação da LC e do PSB paulista e de propaganda de O Homem Livre e dos poucos eventos públicos que realizou, a maioria dos quais, em resposta a passeatas ou eventos da AIB. Ademais, como era uma frente de pequenos grupos e partidos de esquerda que tinham pequeno grupo de militantes e pouquíssima visibilidade política e as articulações que fize- 
ram para a preparação do contracomício de 7 de outubro de 1934 foram realizados pelas respectivas direçôes, os antifascistas que não participaram dessas conversações políticas ou não pertenciam a esses grupos não relacionam a FUA com a "Batalha da Praça da Sé". Assim, a memória histórica do evento não absorveu essa relação política. Existem ainda dois agravantes. Primeiro, o principal partido político de esquerda, o PC, era contrário a FUA e tinha a sua própria política de frente única, o Comitê Antiguerreiro, concorrente do PC. E, segundo, os partidos e grupos políticos que patrocinaram a FUA desapareceram politicamente na segunda metade da década. O movimento trotskista quase que desaparece, sendo substituído por uma nova geração sem relação com a aquela que liderou o movimento na primeira metade da década, organizada em torno de Mário Pedrosa, Lívio Xavier, Aristides Lobo e Rodolfo Coutinho. O PSB foi extinto pelo Estado Novo, assim como os outros partidos de esquerda e só foi "refundado" em meados da década seguinte, com novo perfil e lideranças. O único partido que, embora quase desaparecido durante o Estado Novo, manteve uma ligação com a memória histórica precedente foi certamente o PC. O processo que, na conjuntura estudada, mereceu o cultivo de sua memória foi a ANL e o Levante Comunista de 35, não o processo político anterior.

${ }^{99}$ Ele foi registrado em 9 de outubro de 1934, no livro J-8, no de ordem 12660 junto ao órgão público competente. Cf. Índice de Registro civil das pessoas jurídicas: matrícula de oficinas impressoras e de jornais e outros periódicos. Arquivo Nacional.

${ }^{100}$ Tobias Warshavsky era judeu, militante da Juventude Comunista e cartunista de $A$ Pátria. É famosa a charge de sua autoria, publicada no jornal onde trabalhava, no qual Salomé carrega uma bandeja com a cabeça de São João com o corpo seguindo a forma da suástica nazista. Tobias foi assassinado em 17 ou 18 de outubro de 1934 e seu corpo encontrado nas matas da Floresta da Tijuca, na cidade do Rio de Janeiro. Sua identidade só foi estabelecida em $1^{\circ}$ de novembro. (A Pátria, 1 de novembro de 1934.) O seu assassinato transformou-se num cavalo de batalha propagandístico das esquerdas, especialmente do PCB, que acusava a polícia política de Getúlio pelo crime, que por sua vez acusava o partido. Waack encontrou em Moscou informes do Comintern que confirmam que foram realmente militantes do PCB (Cabeção, Martins, o instrutor alemão Jan Jolles e o próprio Tampinha) os responsáveis pelo assassínio, confirmando o inquérito policial concluído apenas em 1941, embora não haja exata coincidência quanto aos indivíduos. O PCB julgava que ele teria colaborado com a polícia para a prisão do dirigente nacional do Comitê Antiguerreiro, Adelino Deícola dos Santos, o Tampinha. O inquérito policial encontra-se no Fundo DOPS/APERJ.

${ }^{101} \mathrm{O}$ acordo demandou muita negociação e acomodações políticas e concluiu-se na primeira semana do mês. No dia $1^{\circ}$ de outubro, o PSPB, PTB e LCI convocam o PCB etc. para uma reunião na União dos Foguistas na semana seguinte. (A Pátria, 4 de outubro de 1934 , p. 6.) Dois dias depois o PCB, coerente com a política de "frente única pela base", rejeita a proposta afirmando que "a frente deveria ser feita no próprio terreno das lutas operárias em curso e não através de 'conclaves eleitorais" (Vianna. Op. cit., p. 110). Apesar disso, no dia 4 aconteceu, como previsto, a "reunião preparatória da Conferência da Frente Única Proletária” com a presença do PCB (A Pátria, 5 de outubro de 1934. p. 10) 
e se convocou a referida Conferência para o dia 6, que aconteceu e se concluiu com um acordo no qual o PCB “conseguiu que PSPB e LCI aceitassem parte de suas propostas [...] Em função dessas decisões, sob o argumento de que violavam a constituição, o PTB e o PSB se retiraram das negociaçôes" (Cf. Del Roio. Op. cit., p. 246). No dia 11 O Jornal do Povo publica o manifesto-programa da frente eleitoral acordada pelo PCB, LCI e PSPB que abandona a sigla FUP e adota a legenda que o PCB registrara há vários meses, União Operária e Camponesa do Brasil (UOCB).

${ }^{102}$ Comissão: "Grupo de pessoas com funções especiais, ou incumbidas de tratar de determinado assunto". (Hollanda, Sérgio B.de Novo Dicionário Aurélio. Rio de Janeiro: Nova Fronteira, s.d. p. 351).

${ }^{103}$ Para maiores detalhes sobre a CJPI ver nossa tese (Castro. Op. cit.).

${ }^{104}$ No segundo semestre de 1934 e primeiro de 1935.

\section{Resumo}

Em 1933 e 1934 as esquerdas brasileiras criaram organizaçôes para impedir o crescimento do fascismo no Brasil, representado pela Ação Integralista Brasileira (AIB). $O$ Partido Comunista e a "trotskista" Liga Comunista (LC) disputaram a hegemonia neste embate político. Nos últimos meses de 1934 o antifascismo de esquerda teve dois importantes momentos que criaram as condiçôes para sua ampliação política e geográfica: a "Batalha da Praça da Sé" e a criação da Comissão Jurídica e Popular de Inquérito (CJPI) que aglutinou os diferentes grupos politicos antifascistas e progressistas e preparou as bases da formação de um mais amplo movimento político, a Aliança Nacional Libertadora (ANL).

\section{Abstract}

In 1933 and 1934 the Brazilian left created organisations to deal with the increasing offascism in Brazil represented by the Brazilian Integralist Action (Ação Integralista Brasileira). The Communist Party (Partido Comunista) and the "Trotskyte" Communist League (Liga Comunista — LC) disputed the hegemony in this political crusade. In the last months of 1934 the left antifascism had two important moments that created the conditions of its political and geographical enlargement: "The See Square Battle" ("Batalha da Praça da Sé) and the creation of Juridical and Popular Inquiry Commission (Comissão Jurídica e Popular de Inquérito - CJPI). The CJPI agglutinated the different antifascist and progressive political groups and prepared the basis to the formation of a wider political movement, the National Liberator Alliance (Aliança Nacional Libertadora). 